\title{
Late Middle Pleistocene malacofauna of the Palaeolithic site of Valdocarros II, Jarama River valley, Madrid, Spain
}

\author{
María Teresa Aparicio ${ }^{\mathrm{a}}$, Joaquín Panera ${ }^{\mathrm{b}}$ *, Susana Rubio-Jara ${ }^{\mathrm{b}}$, David Uribelarrea ${ }^{\mathrm{c}}$, Alfredo Pérez-González \\ ${ }^{a}$ Departamento de Biodiversidad y Biología Evolutiva, Museo Nacional de Ciencias Naturales (CSIC), C/ José Gutiérrez Abascal 2, 20006, Madrid, Spain \\ ${ }^{\mathrm{b}}$ Centro Nacional de Investigación sobre Evolución Humana (CENIEH), Paseo de la Sierra de Atapuerca s/n, 09002 Burgos, 09004, Burgos, Spain \\ ${ }^{\mathrm{c}}$ Departamento de Geodinámica, Facultad de Ciencias Geológicas, Universidad Complutense de Madrid, C/ Jose Antonio Novais 2, 28040, Madrid, Spain
}

\section{A R T I C L E I N F O}

\section{Keywords:}

Central Spain

Freshwater Mollusca fossils

Land snail fossils

Jarama River

Malacofauna

Pleistocene

\begin{abstract}
A B S T R A C T
Owing to its geographical position relative to northwestern Europe, the Iberian Peninsula was a refuge for many species during periods of harsh environmental conditions in the Quaternary. Despite this, the Pleistocene history of non-marine molluscs in Spain has been scarcely addressed. In this study, we examine the malacofauna of Valdocarros II, a site within the Complex Terrace of Arganda in the Jarama river valley tributary of the Tagus River in central Spain. This large, minutely-excavated site consists of five flood sequences identified in five archaeological levels and has been dated to the late Middle Pleistocene (end MIS 8-beginning MIS 7).

Specimens of twelve freshwater and eighteen land mollusc taxa were identified. The most abundant species observed was Xerotricha madritensis, a land snail endemic to the Iberian Peninsula that today inhabits exposed surfaces with scarce plant cover. The most abundant freshwater species found was Anisus spirorbis, which currently thrives in tributaries of the Jarama River. This malacofauna assemblage features different ecological components, though dry, open-ground terrestrial species predominate. A correspondence analysis of the most frequently appearing land animals and the archaeological levels revealed a slight separation of level 2 from the other levels, indicative of its mesophilous character. However, few differences among these levels were identified in three correspondence analyses performed on the land or freshwater species datasets. Our observations of the malacofauna assemblage of Valdocarros II indicate a site characterized by a temperate climate and open areas with riverside vegetation. Furthermore, we propose the assignment of this site to an interstadial given the observed malacofauna of the five levels.
\end{abstract}

\section{Introduction}

The fossil remains of non-marine molluscs, particularly those from central and northern Europe, have often been used as indicators of continental environmental and climate conditions during the Quaternary (Ložek, 1964, 1990; 2001; Evans, 1972; Puisségur, 1976; Kerney, 1977; Rousseau and Puisségur, 1999; Davies, 2008; Cameron et al., 2010; Osipova et al., 2013 Alexandrowicz et al., 2014; Limondin-Lozouet and Preece, 2014; Limondin-Lozouet et al., 2017). However, knowledge of similar fossils in southern Europe is still poor (Preece, 1991; Zanchetta et al., 2006), despite being a known refuge area for many species during Quaternary glaciations (Hewitt, 1999; Pinceel et al., 2005; Gómez and Lunt, 2006; Zanchetta et al., 2006; Grindon and Davison, 2013). The Iberian Peninsula, given its geographical position, might have ex- perienced the warming effect of Atlantic surface currents during glacial periods, thus providing refuge for some ancestral temperate species of modern fauna and flora of northwestern Europe (Preece, 1991).

Thus far, reconstruction of the evolutionary processes that occurred during this time has been incomplete given the lack of early fossil records of vegetation and faunal assemblages, including molluscs, despite many studies calling for this information (Pinceel et al., 2005; Blain et al., 2012; Nordsieck, 2014; Neiber and Hausdorf, 2015; Razkin et al., 2015). With the exception of the deep-sea vegetation assemblage record off the Portuguese margin, which represents one of the few (and best) Iberian continental sequences from the late Middle Pleistocene (Roucoux et al., 2006), scarce continental data exist for the Pleistocene period in southern Europe, particularly in the Iberian Peninsula (Tzedakis et al., 2003, 2006; 2013; Lézine et al., 2010; Tzedakis, 2010). Even more scarce is data on Quaternary land and freshwater snail fossil

\footnotetext{
* Corresponding author.

Email addresses: teresa@mncn.csic.es (M.T. Aparicio); joaquin.panera@cenieh.es (J. Panera)
} 
groups of the Iberian Peninsula (White et al., 2017), particularly Hygromiidae, given that the main diagnostic features of this group appear on the soft body and genitalia, which rarely fossilize (Aparicio, 1986a). In fact, only a few studies of Pleistocene non-marine molluscs of central Spain exist in the literature (Madurga, 1973; Alférez, 1976; Robles, 1980; Sesé et al., 2004). Therefore, in this study, we examined the malacofauna assemblage of Valdocarros II, a Palaeolithic site located in the Jarama river valley (Madrid) in central Spain. This site belongs to the Complex Terrace of Arganda (Arganda II stratigraphic unit) and was formed by the successive piling of alluvial deposits and has been dated as late Middle Pleistocene (end MIS 8-beginning MIS 7; Panera et al., 2011; Sesé et al., 2011; Blain et al., 2012; Moreno et al., in this volume).

Previous studies have investigated other faunal assemblages and the human lithic industry at Valdocarros II (Panera, 2009; Sesé et al., 2011; Blain et al., 2012; Rubio-Jara et al., 2016). Based on the 3009 worked pieces recovered in these studies, the lithic industry is of the Acheulean type, and its basic technological characteristics are congruent with those seen at other Acheulean sites of the Spanish Meseta (Panera, 2009; Rubio-Jara et al., 2016). In addition, 2750 macromammalian remains were collected: Cervus elaphus was the most represented species, followed by Equus caballus, Bos primigenius and, to lesser extents, Capreolus sp., Dama sp. and Elephas sp. (Yravedra and Domínguez-Rodrigo, 2009) Taphonomically, the bone accumulations from this site are known to be well preserved, although fragmented due to both anthropogenic and fossil diagenetic processes (Yravedra and Domínguez-Rodrigo, 2009). Complementing these studies, our molluscan findings at Valdocarros II provide a better understanding of the climatic, environmental and ecological factors characterizing the central Iberian Peninsula during the late Middle Pleistocene.

\section{Geology and local stratigraphy}

The study area is located in the middle stretch of the Jarama River (Fig. 1A-C). This valley section lies in the continental Tertiary basin (Madrid Basin) in the transition area between intermediate detritic facies (gravels and sands) and central facies (marls to evaporite-gypsum). Terraces were formed by synsedimentary subsidence due to the karstification of the evaporite bedrock during the Middle to Upper Pleistocene. This process formed terraces with alluvial thicknesses of over $50 \mathrm{~m}$ (Pérez-González, 1971; Uribelarrea, 2008). A sequence of 19 terraces of $+8 \mathrm{~m}$ to $+190 \mathrm{~m}$ was previously identified in this valley (Pérez-González, 1994), where the Matuyama-Brunhes inversion was assigned by palaeomagnetism to terraces $+60-65 \mathrm{~m}$ to $+50-55 \mathrm{~m}$ (Pérez-González et al., 2013). These terraces, which are of stepped and perched types upstream, overlap with the oldest ones, giving rise to the Complex Terrace of Arganda (hereafter CTA) over which the current floodplain is set (Pérez-González, 1971, 1994; Panera et al., 2011). The CTA is made up of successively stacked fluvial sequences, named from bottom to top Arganda I, II and III (Fig. 1E), matching terraces +30-32 m, +23-24 m and +18-20 m, respectively (Pérez-González and Uribelarrea del Val, 2002; Panera et al., 2011). According to numerical dating based on Amino Acid Racemisation (AAR), micromammalian compositions and herpetofaunal associations that indicate climatic conditions, Arganda I has been assigned to MIS 11-9 and Arganda II to MIS 8-7 (Panera et al., 2011). A recent electron spin resonance (ESR) dating study also supports these age assignments (Moreno et al., in this volume).

Valdocarros II is in an abandoned meander (Fig. 1D) that eroded previous overbank units in a floodplain hundreds of metres wide (Valdocarros I). The palaeomeander consists of bedload deposits (lateral accretion bar) and, at the bottom, four low-energy fluvial units composed of silt and clay, each $30-50 \mathrm{~cm}$ thick. Valdocarros I has not yet been systematically excavated, though Acheulean lithic tools and faunal remains have been found at this site (Panera et al., 2011).

Each layer of Valdocarros II buries an Acheulean archaeological level designated from bottom to top 0, 1, 2, 3 and 4, respectively (Fig. 1E). The small grain size of its sediments (silt and clay) and the lack of erosion or recently formed structures indicate a very low-energy environment. The site has a weak to absent soil profile development, few distinct traces of bioturbation and a well-preserved fossil record, suggesting a relatively high rate of burial in all five archaeological levels. The excavated surface area of Valdocarros II is $836 \mathrm{~m}^{2}$. Based on AAR dating studies, ages of $245 \pm 47 \mathrm{ka}$ and $262 \pm 07 \mathrm{ka}$ have been proposed for this site, consistent with evidence provided by micromammals (Panera et al., 2011; Sesé et al., 2011). Furthermore, amphibian and reptilian associations recorded in levels 2, 3 and 4 suggest a rapid climate change, possibly corresponding with the transition from MIS 8 to MIS 7 (Blain et al., 2012).

\section{Material and methods}

The malacofauna fossil remains were collected by screening sediments by water obtained during the archaeological excavations of Valdocarros II in 2005. As it was nearly impossible to sieve all of the excavated sediment, sampling was carried out. A total of 795 sediment samples each weighing $30 \mathrm{~kg}(23,850 \mathrm{~kg}$ total) were collected throughout the entire excavated area. Furthermore, if microvertebrate remains were observed, a $2-5 \mathrm{~kg}$ sample was collected from the sediment matrix; in total, 286 of these samples were collected. Spatial coordinates (X, Y, Z) were recorded for all samples.

Wet sieving of the collected sediment was then performed. This procedure disaggregates the sediment and removes the silt-clay matrix, leaving a concentrate enriched with fossil remains. The samples were first dried then immersed into water to ease disaggregation. The samples were then pressure washed on a table that had two sieving sets, one with a mesh size of $2 \mathrm{~mm}$ and the other with a mesh size of $0.5 \mathrm{~mm}$. These sizes ensured that the smallest fossil remains were retained and the clay matrix removed. The resulting fractions were then sorted: the sediment remaining in the $2 \mathrm{~mm}$ sieve was sorted by eye and the sediment in the $0.5 \mathrm{~mm}$ sieve was sorted with binocular lens, due to the potential presence of smaller fossil remains.

For taxonomical identifications, the mollusc collection of the Museo Nacional de Ciencias Naturales (MNCN, Madrid, Spain) and our personal collection were used for comparisons. Overall, the state of conservation of all examined samples was excellent, as exemplified in Fig. 2 in which the shell bands of Cepaea nemoralis can readily be distinguished.

To further support the identification of Xerotricha madritensis fossil specimens, present-day samples of this species from Oitura (Zaragoza) and Mora (Toledo), identified through genital characters, were used as references. SEM and CT scans of these samples were performed at the microscopy facilities of the MNCN.

To detect differences among the five recognized archaeological levels of Valdocarros II, a correspondence analysis (CA) of the identified freshwater and terrestrial molluscs was performed (Figs. 4 and 5). Given the low resolution obtained using all identified land species (18 in total), we performed a second CA excluding the six least frequently found species (i.e. Truncatellina cylindrica, Vertigo angustior, Pupilla muscorum, Acanthinula aculeata, Euconulus fulvus and Deroceras or Limax sp.).

\section{Results}

Our malacological analysis identified a total of twelve freshwater (Table 1) and eighteen terrestrial (Table 2) mollusc taxa in the sedi- 

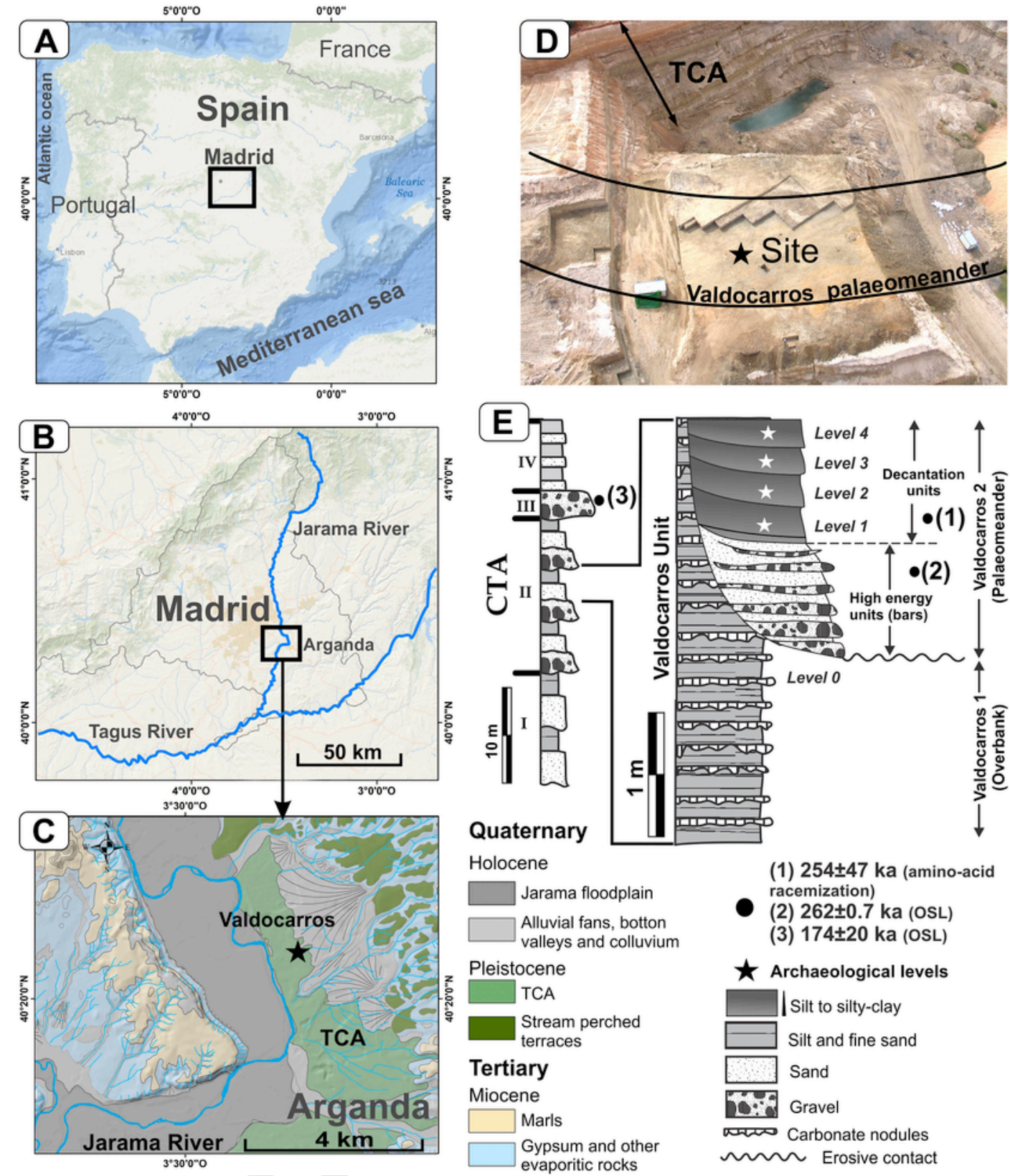

(1) $254 \pm 47$ ka (amino-acid

racemization)

(2) $262 \pm 0.7 \mathrm{ka} \mathrm{(OSL)}$

(3) $174 \pm 20$ ka (OSL)

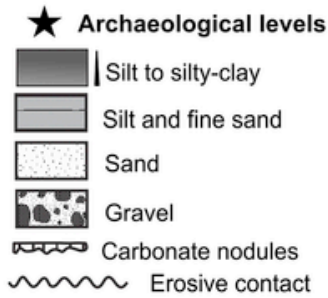

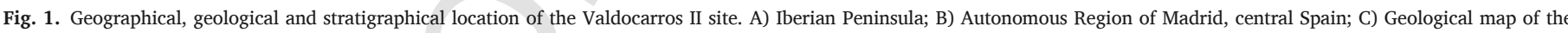

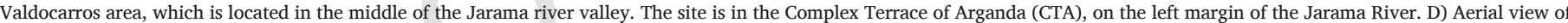

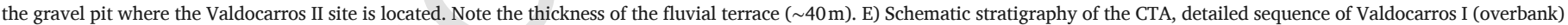
and II (paleomeander). Samples were taken from levels 0-4).

ment samples from Valdocarros II, indicating the predominance of land species at this site. No marine taxa were detected.

The freshwater species appearing most frequently was Anisus spirorbis (63\% MNI) followed by Valvata piscinalis (19\%) (Table 1). Remaining freshwater taxa were detected in lower MNI percentages (less than $7 \%$ ). Nowadays, Anisus spirorbis no longer inhabits the Jarama River, although it has been observed in the Henares, one of its tributaries (Soler et al., 2006). The species is common from Europe to Siberia and is typically found in temporary or calm natural waters in riverside plains; in conditions of drought, it may be found buried in mud (Soler et al., 2006; Bragado et al., 2010; Welter-Schultes, 2012). Valvata piscinalis does not currently inhabit any of the rivers around the Valdocarros II site, most likely due to water pollution. Although this species is not present in the Community of Madrid, it has been cited for other ar- eas of Spain (Alférez, 1976; Vidal-Abarca and Suárez, 1985). It is common in the Palaearctic region, particularly across West Eurasia (Welter-Schultes, 2012), where it typically thrives in clear-standing, well-oxygenated and slow-moving waters of deep $(50 \mathrm{~m})$ rivers or lakes (Girod et al., 1980; Larraz and Equisoain, 1993). It also shows a preference for muddy or silty substrates (Kerney, 1999). With the exception of Valvata piscinalis, the freshwater mollusc taxa found at the site are the same as those currently inhabiting the less disturbed habitats within this area (Soler et al., 2006). Furthermore, seven of the eight freshwater gastropods species identified are pulmonates (Valvata piscinalis is the exception), indicating the capacity to also live outside of the water on riverside vegetation. In terms of the abundances by archaeological level, level 1 was the richest based on the total number of freshwater specimens identified (32\%) (Table 1). Levels 2 and 3 showed similar 


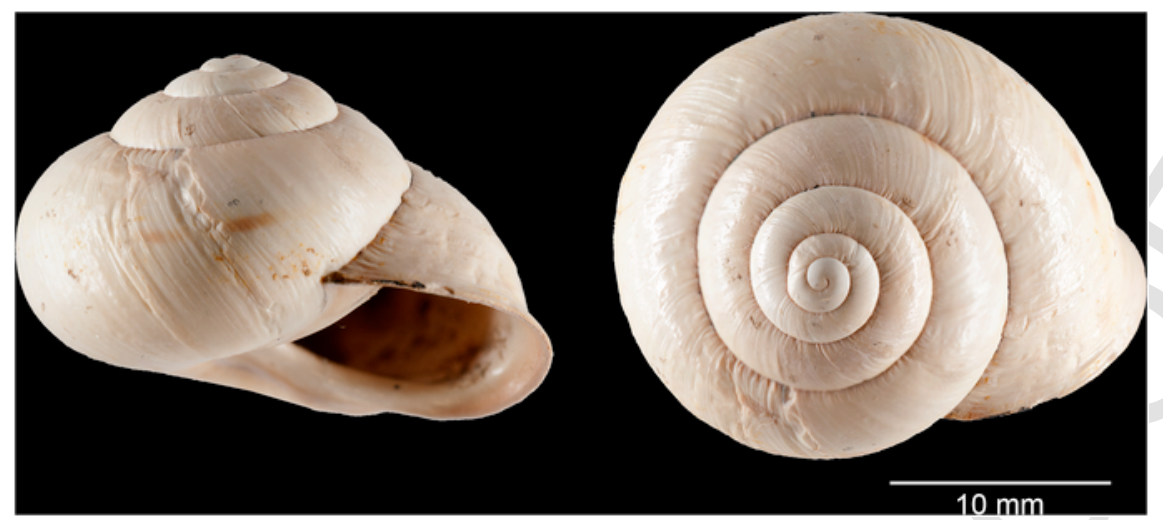

Fig. 2. Cepaea nemoralis (Valdocarros, Level 3). Scale bar $=10 \mathrm{~mm}$.

Table 1

Minimum number of individuals (MNI) recorded for freshwater mollusc taxa identified in the five archaeological levels of the Valdocarros II site.

\begin{tabular}{|c|c|c|c|c|c|c|c|c|}
\hline \multicolumn{9}{|c|}{ Freshwater Molluscs } \\
\hline \multicolumn{2}{|c|}{ Species } & \multirow[t]{2}{*}{ level 0} & \multirow{2}{*}{$\begin{array}{l}\text { level } 1 \\
2\end{array}$} & \multirow[t]{2}{*}{ level 2} & \multirow[t]{2}{*}{ level 3} & \multirow[t]{2}{*}{ level 4} & \multirow{2}{*}{$\begin{array}{l}\text { total MNI } \\
2\end{array}$} & \multirow{2}{*}{$\begin{array}{l}\text { MNI \% } \\
0.33\end{array}$} \\
\hline 1 & Pisidium casertanum (Poli, 1791) & & & & & & & \\
\hline 2 & Pisidium subtruncatum (Malm, 1855) & & 1 & & & & 1 & 0.16 \\
\hline 3 & Pisidium sp & & & & & 1 & 1 & 0.16 \\
\hline 4 & Potomida littoralis (Cuvier, 1798) & & 1 & & & & 1 & 0.16 \\
\hline 5 & Valvata piscinalis (O.F.Müller, 1774) & 2 & 35 & 28 & 30 & 22 & 117 & 19.15 \\
\hline 6 & Ancylus fluviatilis (O.F.Müller, 1774) & & & 1 & 1 & 1 & 3 & 0.49 \\
\hline 7 & Anisus spirorbis (Linnaeus, 1758) & 10 & 134 & 101 & 100 & 39 & 384 & 62.85 \\
\hline 8 & Gyraulus crista (Linnaeus, 1758) & & & 1 & & & 1 & 0.16 \\
\hline 9 & Gyraulus albus (O.F. Müller, 1774) & 1 & 7 & 11 & 7 & 10 & 36 & 5.89 \\
\hline 10 & Radix balthica (O.F. Müller, 1774) & & & 2 & & 5 & 7 & 1.15 \\
\hline 11 & Radix labiata (Rossmässler, 1835) & 15 & 11 & 6 & 2 & 6 & 40 & 6.55 \\
\hline \multirow[t]{3}{*}{12} & Lymnaeidae sp & & 5 & 8 & 4 & 1 & 18 & 2.94 \\
\hline & Total & 28 & 196 & 158 & 144 & 85 & 611 & \\
\hline & $\%$ & 4.58 & 32.08 & 25.86 & 23.57 & 13.91 & & 100 \\
\hline
\end{tabular}

$\mathrm{MNI}=$ minimum number of individuals.

Table 2

Minimum number of individuals (MNI) recorded for land mollusc taxa identified in the five archaeological levels of the Valdocarros II site.

\begin{tabular}{|c|c|c|c|c|c|c|c|c|}
\hline \multicolumn{9}{|c|}{ Terrestrial molluscs } \\
\hline \multicolumn{2}{|c|}{ Species } & \multirow[t]{2}{*}{ level 0} & \multirow{2}{*}{$\begin{array}{l}\text { level } 1 \\
6\end{array}$} & \multirow{2}{*}{$\begin{array}{l}\text { level } 2 \\
2\end{array}$} & \multirow{2}{*}{$\begin{array}{l}\text { level } 3 \\
1\end{array}$} & \multirow{2}{*}{$\begin{array}{l}\text { level } 4 \\
1\end{array}$} & \multirow{2}{*}{$\begin{array}{l}\text { total MNI } \\
10\end{array}$} & \multirow{2}{*}{$\begin{array}{l}\text { MNI \% } \\
0.09\end{array}$} \\
\hline 1 & Cochlicopa lubricella (Porro, 1838) & & & & & & & \\
\hline 2 & Truncatellina cylindrica (Férussac, 1807) & 2 & & 2 & & & 4 & 0.03 \\
\hline 3 & Truncatellina callicratis (Scacchi, 1833) & & 11 & 23 & 1 & & 35 & 0.30 \\
\hline 4 & Vertigo angustior (Jeffreys, 1830) & 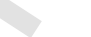 & & 1 & & & 1 & 0.01 \\
\hline 5 & Pupilla muscorum (Linnaeus, 1758) & & 1 & 1 & 1 & 1 & 4 & 0.03 \\
\hline 6 & Vallonia costata (O.F. Müller, 1774) & 1 & 264 & 580 & 209 & 2 & 1056 & 9.07 \\
\hline 7 & Vallonia excentrica (Sterki, 1892) & & 4 & 6 & 3 & & 13 & 0.11 \\
\hline 8 & Acantinula aculeata (O.F. Müller, 1774) & & 1 & & & & 1 & 0,01 \\
\hline 9 & Punctum pygmaeum (O.F. Müller, 1774) & 6 & 29 & 84 & 33 & & 152 & 1.31 \\
\hline 10 & Discus rotundatus (O.F. Müller, 1774) & 3 & 32 & 27 & 20 & 25 & 107 & 0.92 \\
\hline 11 & Vitrea contracta (Westerlund, 1871) & 1 & 88 & 285 & 85 & 1 & 460 & 3.95 \\
\hline 12 & Oxychilus sp & & 9 & 6 & 3 & 1 & 19 & 0.16 \\
\hline 13 & Euconulus fulvus (O.F. Müller, 1774) & & 2 & & & & 2 & 0.02 \\
\hline 14 & Deroceras o Limax $\mathrm{sp}$ & & & & 1 & & 1 & 0.01 \\
\hline 15 & Clausilia sp & 2 & 64 & 55 & 37 & 9 & 167 & 1.43 \\
\hline 16 & Helicella itala (Linnaeus, 1758) & & 5 & 1 & 13 & 1 & 20 & 0.17 \\
\hline 17 & Xerotricha madritensis (Rambur, 1868) & 168 & 3612 & 2130 & 2270 & 1132 & 9312 & 80.01 \\
\hline \multirow[t]{3}{*}{18} & Cepaea nemoralis (Linnaeus, 1758) & 4 & 146 & 37 & 59 & 28 & 274 & 2.35 \\
\hline & Total & 187 & 4274 & 3240 & 2736 & 1201 & 11,638 & \\
\hline & $\%$ & 1.61 & 36.72 & 27.84 & 23.51 & 10.32 & & 100 \\
\hline
\end{tabular}

$\mathrm{MNI}=$ minimum number of individuals.

MNI abundances (26\% and 24\%, respectively), followed by level 4 (14\%), which was significantly specimen poor. Level 0 was both specimen and species poor (abundance less than $5 \%$ ).

Of the 18 land malacofauna species identified (Table 2), the most abundant one, by far, was Xerotricha madritensis ( $80 \% \mathrm{MNI})$, making it the dominant species. Given the abundance of this species and the difficulty of identifying species of the Hygromiidae family only using shell features, these fossil specimens were compared with present day Xerotricha madritensis specimens by CT scanning and SEM. The high similarity detected between specimens indicate that the fossils are indeed 
Xerotricha madritensis (Fig. 3). Appearing at much lower abundances at Valdocarros II were Vallonia costata (9\%), Vitrea contracta (4\%) and Cepaea nemoralis $(\sim 2.5 \%)$. All other terrestrial gastropods appeared at lower percentages. Similar to the freshwater mollusc dataset, level 1 presented the largest terrestrial gastropod MNI (37\%) followed by levels 2, 3, 4 and 0, respectively (Table 2). Consistent with this, the largest number of Xerotricha madritensis samples were found in level 1, although all levels showed high values of this species.

Species compositions and abundances among the archaeological levels were compared by correspondence analysis (CA) (Figs. 4 and 5). Analysis of the complete land species dataset showed the concentration of species and levels close to the origin of the coordinate axes in the CA plot. Thus, to improve the resolution, we repeated the analysis excluding the six taxa appearing at the lowest frequencies, i.e. Truncatellina cylindrica, Vertigo angustior, Pupilla muscorum, Acanthinula aculeata, Euconulus fulvus and Deroceras or Limax sp. In the resulting CA plot (Fig. 4), level 2 appears at a slight distance from the other levels. This level is characterized by the species Truncatellina callicratis, Vallonia costata,
Vallonia excentrica, Punctum pygmaeum and Vitrea contracta. Levels 1 and 3 appear close to the origin of the coordinate axes, and levels 0 and 4 group together in the lower right quadrant of the plot. According to our results, the $\mathrm{x}$-axis defined by the five levels was the discriminant factor in this analysis. In the CA of the freshwater species (Fig. 5), the five levels grouped together near the y-axis with the exception of level 0 , which is characterized by Radix labiata, the most abundant species found in this level.

\section{Discussion}

The mollusc association of Valdocarros II presents both freshwater and terrestrial taxa; however, based on species and specimen numbers, land species clearly dominate. In addition, nearly all of the identified freshwater gastropod species are able to live outside of the water, consistent with the site being an abandoned meander of the Jarama River (Panera et al., 2011).

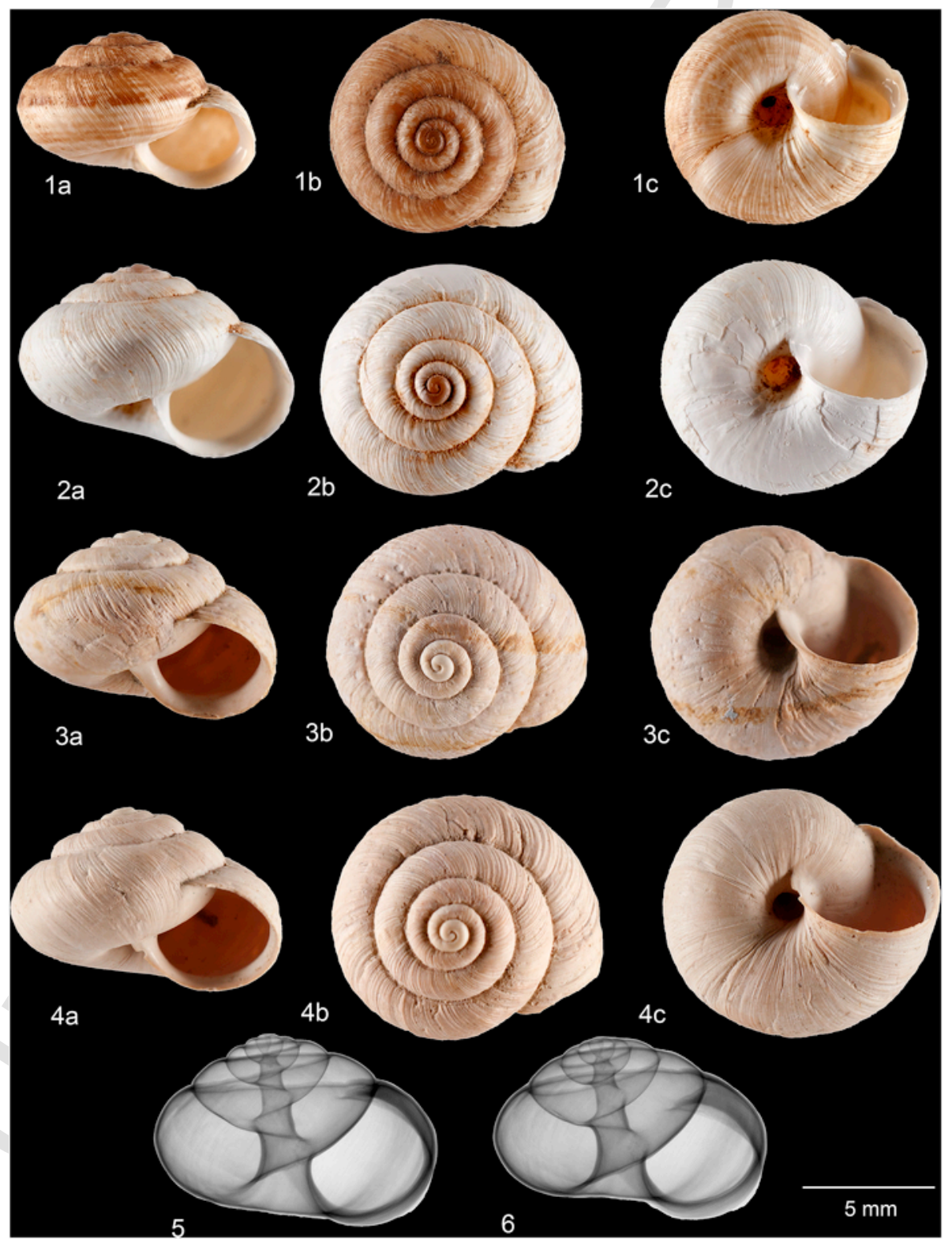

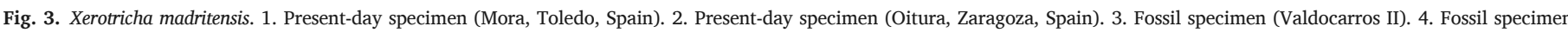
(Valdocarros II, Level 2). 5. CT scan of an Oitura specimen. 6. CT scan of a Valdocarros II specimen. Scale bar $=10 \mathrm{~mm}$. 


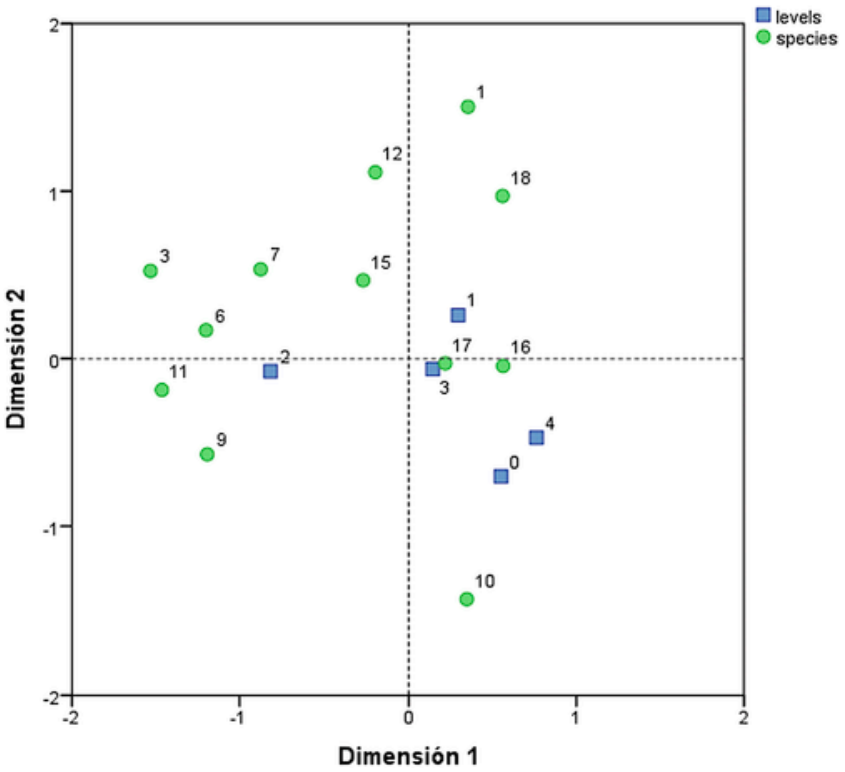

Fig. 4. Summary of the results of the correspondence analysis performed using the MNI data for the 12 most abundant land species identified in the five archaeological levels. Species 1 Cochlicopa lubricella (Porro, 1838); Species 3 Truncatellina callicratis (Scacchi, 1833); Species 6 Vallonia costata (O.F. Müller, 1774); Species 7 Vallonia excentrica (Sterki, 1892); Species 9 Punctum pygmaeum (O.F. Müller, 1774); Species 10 Discus rotundatus (O.F. Müller, 1774); Species 11 Vitrea contracta (Westerlund, 1871); Species 12 Oxychilus sp.; Species 15 Clausilia sp.; Species 16 Helicella itala (Linnaeus, 1758); Species 17 Xerotricha madritensis (Rambur, 1868); Species 18 Cepaea nemoralis (Linnaeus, 1758).

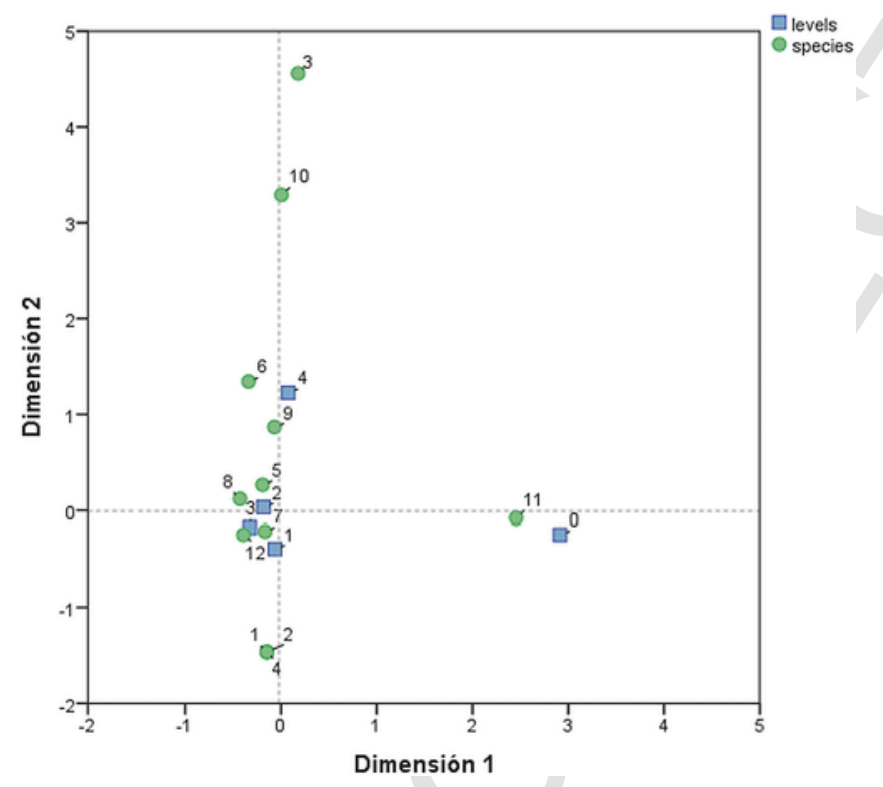

Fig. 5. Summary of the results of the correspondence analysis performed using the MNI data for the 12 freshwater species identified in the five archaeological levels. Species 1 Pisidium casertanum (Poli, 1791); Species 2 Pisidium subtruncatum Malm 1855; Species 3 Pisidium sp.; Species 4 Potomida littoralis (Cuvier, 1798); Species 5 Valvata piscinalis (O.F.Müller, 1774); Species 6 Ancylus fluviatilis (O.F.Müller, 1774); Species 7 Anisus spirorbis (Linnaeus, 1758); Species 8 Gyraulus crista (Linnaeus, 1758); Species 9 Gyraulus albus (O.F. Müller, 1774); Species 10 Radix balthica (O.F. Müller, 1774); Species 11 Radix labiata (Rossmässler, 1835); Species 12 Lymnaeidae spp.

The mollusc remains of Valdocarros II are well preserved with very few damaged, chipped or roll-marked specimens recovered. This suggests their quick burial in the sediment and minimal transport, consist with what has been described for small mammals (Sesé et al., 2011). Their occurrence close to the area of initial deposition is in line with the site being a former overbank deposit. In terms of specimen sizes, most were found in the fine $(0.5 \mathrm{~mm})$ fraction. Ten of the eighteen terrestrial taxa examined were small $(<5 \mathrm{~mm}$ ) (i.e. Euconulus fulvus, Vitrea contracta, Punctum pygmaeum, Pupilla muscorum, Vallonia costata, Vallonia excentrica, Acanthinula aculeata, Truncatellina cylindrica, Truncatellina callicratis and Vertigo angustior). Nine of the twelve freshwater taxa identified were also found in the fine fraction; only Potomida littoralis, Radix balthica and Ancylus fluviatilis were found in the course fraction. These findings demonstrate the importance of using very meticulous methods to extract material from archaeological sites.

The malacofauna assemblage of this site highlights several ecological factors. Dry open-ground species (xerophiles) predominate in the land group, but species typical of marshes and humid sites, ubiquitous zones and semi-woodlands are also present (Evans, 1972; Puisségur, 1976; Puente, 1994; Kerney and Cameron, 1979; Kerney, 1999; Bragado et al., 2010; Welter-Schultes, 2012; www.animalbase.uni-goettingen.de). The freshwater assemblage is characterized by species that thrive in the calm waters of riverside plains and are able to survive in mud during periods of drought and by species inhabiting clear-standing, well-oxygenated and slow-moving river waters (Larraz and Equisoain, 1993; Kerney, 1999; Soler et al., 2006; Bragado et al., 2010; Welter-Schultes, 2012). The formation of this site at an abandoned meander may explain the observed biodiversity of the freshwater and terrestrial malacofauna. Among the freshwater molluscs found, Potomida littoralis, Valvata piscinalis, Anisus spirorbis and Gyraulus albus show a preference for dam waters, supporting the idea that this site previously contained overbank deposits.

The malacofaunal fossils are similar to present-day molluscs. All of the species identified, except Valvata piscinalis, inhabit nearby regions of the Valdocarros II site, although in differing abundances and community compositions. Surrounding regions of Valdocarros currently show a greater diversity and number of xerophilous species, while species associated with humid climates are missing (e.g. Vertigo angustior; Gómez-Moliner et al., 2008; Bragado et al., 2010). This is unsurprising given the intense habitat transformation experienced by Madrid and neighbouring Valdocarros (e.g. deforestation, desertification, biotope degradation, biotope disappearance and water pollution). However, Valvata piscinalis has been cited for the Tagus river terrace in Toledo (in the neighbouring region of Castilla-La Mancha) (Alférez, 1976), which is older in age to Valdocarros II.

The molluscs of Valdocarros II can be described as a mesophilous assemblage. Its dominant species, Xerotricha madritensis, an endemic of the Iberian Peninsula, is a xerophilous taxon that inhabits exposed surfaces with scarce plant cover but also thrives in ruderal biotopes under herbaceous vegetation and stones. The species is also tolerant of semi-arid conditions (Aparicio, 1986b; Puente, 1994; Bragado et al., 2010). Our study suggests this species was more abundant in this region during the Pleistocene than it is today, which should be further investigated.

The semi-woodland habitat was poorly represented: only $3.3 \%$ of all specimens found could be assigned to this group if Cepaea nemoralis, Discus rotundatus and Acathinula aculeata are also considered indicators of this habitat. In contrast, species showing a preference for dry open environments, including Truncatellina cylindrica, Truncatellina callicratis, Pupilla muscorum, Vallonia costata, Vallonia excentrica, Helicella itala and Xerotricha madritensis, represented nearly $90 \%$ of the total number of specimens, clearly indicating a dry open habitat for Valdocarros II.

Our correspondence analysis comparing the most frequently appearing terrestrial mollusc species among the archaeological levels revealed the slight distancing of level 2 (Fig. 4). This level is characterized by the species Truncatellina callicratis, Vallonia costata, Vallonia excentrica, Punctum pygmaeum, and Vitrea contracta. The habitats described for these species, such as semi-woodland or bare land with some moisture (Evans, 1972; Puisségur, 1976; Puente, 1994; Kerney and Cameron, 1979; Kerney, 1999; Bragado et al., 2010; Welter- 
Schultes, 2012), indicate, to some extent, a less xerophilous or mesophilous character. Such ecological preferences seem consistent with information provided by other proxies identified at this site (Blain et al., 2012). Taken together, the data suggest that level 2 is characterized by a temperate semi-humid climate influenced by the Atlantic Ocean. Nevertheless, the correspondence analyses overall indicate that no major differences exist among the archaeological levels.

According to the ecological characteristics of the assemblage, the climate inferred for Valdocarros II is not much colder or wetter than the one today. Hence, the species association observed in this study is characteristic of the central Iberian Peninsula Meseta, which has a continental climate with cool winters and dry sunny summers. The species are thus moderately cold tolerant and highly tolerant of semi-arid conditions. The difference in mean annual temperature between 'cold' and 'warm' periods is estimated at $3.2^{\circ} \mathrm{C}$, increase more during winter $\left(+3{ }^{\circ} \mathrm{C}\right)$ than summer $\left(+1{ }^{\circ} \mathrm{C}\right)$ (Blain et al., 2012). These climate characteristics are similar to those described for other associations found at this site, including small mammals (Sesé et al., 2011), herpetofauna (Blain et al., 2012; Blain et al., in this volume) and vegetation (Ruiz-Zapata et al., in this volume). Moreover, a temperate climate (mesophilous), which would provide plant cover, riverside vegetation and open areas, may also explain the presence of the freshwater mollusc taxa described in this assemblage.

Seven of the species found at Valdocarros II (Cepaea nemoralis, Punctum pygmaeum, Discus rotundatus, Vallonia costata, Limax sp1, Clausilia sp1 and Anisus spirorbis) have also been cited for Áridos 1, a nearby site located on the Arganda I unit (Robles, 1980). According to AAR and ESR dating, Arganda I can be chronologically assigned to between MIS 11 and MIS 9 (Panera et al., 2011; Moreno et al., in this volume), making it stratigraphically older than Valdocarros II. However, Valdocarros II is richer than Áridos 1 in terms of species and specimen numbers, likely due to the difference in excavation surface areas of the two sites. In contrast, Xerotricha madritensis (and related taxa) are absent at Áridos 1 , which is surprising given its high abundance at Valdocarros II and its presence in the Pleistocene terraces of the Tagus River in central Spain (Toledo) (Sesé et al., 2004). Ecological and climatic differences between sites may account for the absence of this (and related) species. Valdocarros II is in an abandoned meander away from the main channel of the Jarama River, whereas Áridos 1 is in a floodplain closer to the main channel. Furthermore, the timing of the formation of Valdocarros II is associated with a colder climate than Áridos 1 (Yravedra et al., 2010, Blain et al., 2014; Blain et al., in this volume).

Helicella itala has been cited for Padul in the Granada province (Madurga, 1973), a site of similar Pleistocene age (though dated with less precision) as Valdocarros II. Its presence at Valdocarros II, although scarce (Table 2), is interesting because this site is at the southern limit of the modern distribution range of this species (Puente, 1994; Bragado et al., 2010). Similarly, the presence of Cepaea nemoralis in the Valdocarros II malacofauna assemblage is viewed as an old record at the edge of the southern limit of this species current distribution range (Puente, 1994; Bragado et al., 2010).

As previously mentioned, there is little data on Quaternary continental molluscs of the Iberian Peninsula, highlighting the importance of the results presented in this work. However, the lack of other studies for comparison makes evaluating palaeoclimatic conditions derived from the fauna assemblages difficult. Index species of cold periods have been identified from central and northern Europe; however, these species are not present in Valdocarros II (Ložek, 1964, 2001; Horsák et al., 2010). Moreover, the malacological assemblages of central Spain are very different from those of central and northern Europe. On the other hand, the malacofauna assemblage of Valdocarros II is, for the most part, comprised of species that still live in the central Iberian
Peninsula. Therefore, our hypothesis is that Valdocarros II was characterized by a warm and dry climate, similar to the present-day climate of the region. During cold periods, the degree of aridity is known to increase (Roucoux et al., 2006; Tzedakis et al, 2013; Zanchetta et al., 2017). Smaller snail species appear to survive adverse conditions, including cold ones, better than larger species (Ansart and Vernon, 2003). Thus, the lower abundance of specimens of small-sized species and the greater abundance of specimens considered medium-sized species (i.e. Cepaea nemoralis and Xerotricha madritensis) at Valdocarros II indicate warm conditions rather than cold ones. Furthermore, previously published faunal assemblages, and the climatic conditions derived from them, indicate that the Valdocarros II site is from MIS 8 to MIS 7 (Sesé et al., 2011; Blain et al., 2012, 2014). Taken together with our data, we hypothesize that Valdocarros II might belong to a warm period that could be assigned to the interstadial Transition III (TIII) (Blain et al., 2012; Osipova et al., 2013).

\section{Conclusions}

Our study examined the malacofauna assemblage of the Valdocarros II site at Arganda II to provide insight into the diversity and abundance of molluscs present in the Iberian Peninsula during the late Middle Pleistocene. Both freshwater and terrestrial species were found though open-ground land species dominate the assemblage, particularly $\mathrm{Xe}$ rotricha madritensis. Moreover, most of the species representative of Valdocarros II are the same as those found in nearby regions, although in differing abundances and compositions. This is consistent with our hypothesis about the climatic conditions of Valdocarros II being temperate, similar to today's climate. Furthermore, our findings suggest that Valdocarros II might be associated with a warm period of the interstadial Transition III, though this hypothesis requires further research.

\section{Acknowledgments}

The field work received financial support from the Dirección General de Patrimonio Histórico (PR170/04-13244; PR42/05-14071; 1962/ 2006/00) and the Dirección General de Investigación of the Comunidad de Madrid (06/123/2003). The authors thank Rafael Araujo for the bivalve determinations, Richard Preece for help with one of the species identifications, Carmen Sesé for providing the study material, Enrique Baquedano for facilitating the use of the washing table and Nuria Gallego, Iván González, Primitivo Sanabria and Miguel Díaz for supervising the field work. We also thank Teresa Pérez, Pilar García, Marta Furio and Laura Tormo for technical assistance, Laura Barrios for help with the statistical analysis, Jesús Muñoz for photographs, Ana Burton for editorial assistance and Melinda Modrell for the careful English language review.

\section{References}

Alexandrowicz, W.P., Łanczont, M., Boguckyj, A.B., Kulesza, P., Dmytruk, R., 2014. Molluscs and Ostracods of the Pleistocene loess deposits in the Halych site (Western Ukraine) and their significance for palaeoenvironmental reconstructions. Quat. Sci. Rev. 105, 162-180.

Alférez, F., 1976. Una asociación de moluscos fósiles fluviales del Pleistoceno medio (Mindel) del río Tajo. Bol. Real Soc. Esp. Hist. Nat. (Geol.) 74, 5-17.

Ansart, A., Vernon, P., 2003. Cold hardiness in molluscs. Acta Oecol. 24, 95-102.

Aparicio, M.T., 1986a. Consideraciones sobre el valor taxonómico de los caracteres utilizados en la determinación de las especies de la familia Helicidae de España Peninsular. Iberus 6 (1), 131-140.

Aparicio, M.T., 1986b. Helicella madritensis (Rambur, 1868) en las Lagunas de Ruidera (España). Iberus 6 (2), 265-268.

Blain, H.-A., Panera, J., Uribelarrea, D., Rubio-Jara, S., Pérez-González, A., 2012. Characterization of a rapid climate shift at the MIS $8 / 7$ transition in central Spain (Valdocarros II, Autonomous Region of Madrid) by means of the herpetological assemblages. Quat. Sci. Rev. 47, 73-81. 
Blain, H.-A., Santonja, M., Pérez-González, A., Panera, J., Rubio-Jara, S., 2014. Climate and environments during marine isotope stage 11 in the central Iberian Peninsula: the herpetofaunal assemblage from the Acheulean site of Áridos-1, Madrid. Quat. Sci. Rev. 94, 7-21.

Blain, H.A., Bisbal-Chinesta, J.F., Martínez-Monzón, A., Panera, J., Rubio-Jara, S., Uribelarrea, D., Yravedra, J., Pérez-González, A., in this volume. The Middle to Late Pleistocene herpetofaunal assemblages from the Jarama and Manzanares Valleys (Madrid, central Spain). Ecol. Synth.

Bragado, M.D., Araujo, R., Aparicio, M.T., 2010. Atlas y Libro Rojo de los Moluscos de Castilla-La Mancha. Organismo Autónomo Espacios naturales de Castilla-La Mancha, Guadalajara, 506

Cameron, R.A.D., Pokryszko, B.M., Horsák, M., 2010. Land snail faunas in Polish forests: patterns and composition in a post-glaciar landscape. Malacologia 53 (1), 77-134. https://doi.org/10.4002/040.053.0105.

Davies, P., 2008. Snails Archaeology and Landscape Change. Oxbow Books, Oxford.

Evans, J.G., 1972. Land Snails in Archaeology. With Special Reference to the British Isles. Seminar Press, London and New York.

Girod, A., Bianchi, I., Mariani, M., 1980. Gasteropodi, 1(Gasteropoda: Pulmonata Prosobranchia: Neritidae, Viviparidae, Bithynidae, Valvatidae). Guide per il reconoscimento delle specie animale delle acque interne italiane 7, 1-86.

Gómez, A., Lunt, D.H., 2006. Refugia within refugia: patterns of phylogeographic concordance in the Iberian Peninsula. In: Weiss, S., Ferrand, N. (Eds.), Phylogeography of Southern European Refugia. Springer, The Netherlands, pp. 155-188.

Gómez-Moliner, B., Martínez- Ortí, A., Altonaga, K., Puente, A.I., Prieto, C.E., 2008. Vertigo (Vertilla) angustior Jeffreys, 1839. pp. 337-340. In: Verdú, J.R., Galante, E. (Eds.), Atlas de los Invertebrados amenazados de España (Especies en peligro crítico y en peligro). Dirección General para la Biodiversidad. Ministerio de Medio Ambiente, Madrid, p. 340 .

Grindon, A.J., Davison, A., 2013. Irish Cepaea nemoralis land snails have a Cryptic Franco-Iberian origin that is most easily explained by the movements of Mesolithic humans. PLoS One 8 (6), e65792https://doi.org/10.1371/journal.pone.0065792.

Hewitt, G.M., 1999. Post-glacial re-colonization of European biota. Biol. J. Linn. Soc. 68, $87-112$

Horsák, M., Chytrý, M., Pokryszko, B.M., Danihelka1, J., Ermakov, N., Hájek, M., Hájková, P., Kintrova, K., Koci, M., Kubesova, S., Lustyk, P., Otýpkova, Z., Pelánkova, B., Valachovic, M., 2010. Habitats of relict terrestrial snails in southern Siberia: lessons for the reconstruction of palaeoenvironments of full-glacial Europe. J. Biogeogr. 37, 1450-1462. https://doi.org/10.1111/j.1365-2699.2010.02280.

Kerney, M.P., 1977. A proposed zonation scheme for late-glacial and postglacial deposits using land Mollusca. J. Archaeol. Sci. 4, 387-390.

Kerney, M.P., 1999. Atlas of the Land and Freshwater Molluscs of Britain and Ireland. Harley Books, Essex England, 264.

Kerney, M.P., Cameron, R.A.D., 1979. A Field Guide to the Land Snails of Britain and North-west Europe, London. Collins, 287.

Larraz, M.L., Equisoain, J.J., 1993. Moluscos terrestres y acuáticos de Navarra (Norte de la Península Ibérica). Publicaciones de Biología de la Universidad de Navarra, Serie Zoológica 23, Pamplona, 326

Lézine, A.M., Von Grafenstein, U., Andersen, N., Belmecheri, S., Bordon, A., Caron, B., Cazet, J.P., Erlenkeuser, H., Fouache, E., Grenier, C., Huntsman-Mapila, P., Hureau-Mazaudier, D., Manelli, D., Mazaud, A., Robert, C., Sulpizio, R., Tiercelin, J.J., Zanchetta, G., Zeqollari, Z., 2010. Lake Ohrid, Albania, provides an exceptional multi-proxy record of environmental changes during the last glacial-interglacial cycle. Palaeogeogr. Palaeoclimatol. Palaeoecol. 287, 116-127.

Limondin-Lozouet, N., Preece, R.C., 2014. Quaternary perspectives on the diversity of land snail assemblages from northwestern Europe. J. Molluscan Stud. 80, 224-237. https: //doi.org/10.1093/mollus/eyu047.

Limondin-Lozouet, N., Villa, V., Pereira, A., Nomade, S., Bahain, J.J., Stoetzel, E., Aureli, D., Nicoud, E., 2017. Middle Pleistocene molluscan fauna from the Valle Giumentina (Abruzzo, Central Italy): palaeoenvironmental, biostratigraphical and biogeographical implications. Quat. Sci. Rev. 156, 135-149 https://doi.org/10.1016/j.quascirev.2016. 11.029.

Ložek, V., 1964. Quartärmollusken der Tschechoslowakei. Rozpr. Ústred. Ústavu Geol. 31, $1-374$.

Ložek, V., 1990. Molluscs in loess, their paleoecological significance and role in Geochronology - principles and methods. Quat. Int. 7/8, 71-79.

Ložek, V., 2001. Molluscan fauna from the loess series of Bohemia and Moravia. Quat. Int. 76/77, 141-156.

Madurga, M.C., 1973. Los Gasterópodos dulceacuicolas y terrestres del Cuaternario español. Bol. Real Soc. Esp. Hist. Nat. (Geol.) 71, 43-166.

Moreno, D., Duval, M., Rubio-Jara, S., Panera, J., Bahain, J. J., Shao, Q., Pérez-González, A., Falguères, C., in this volume. ESR dating of Middle Pleistocene archaeo-paleontological sites from the Manzanares and Jarama river valleys (Madrid basin, Spain). Quat. Int. https://doi.org/10.1016/j.quaint.2017.09.003.

Neiber, M.T., Hausdorf, B., 2015. Molecular phylogeny reveals the polyphyly of the snail genus Cepaea (Gastropoda: Helicidae). Mol. Phylogenet. Evol. 93, 143-149.

Nordsieck, H., 2014. Annotated check-list of the genera of fossil land snails (Gastropoda: Stylommatophora) of western and central Europe (Cretaceous - Pliocene) with description of new taxa. Arch. Molluskenkd. 143 (2), 153-185.

Osipova, E., Danukalova, G., Markovic, S.B., 2013. Malacological characteristics of the Middle to Upper Pleistocene transitional interval (MIS 7-5) observed in the Batajnica locality (Serbia). Quat. Int. 292, 86-100.

Panera, J., 2009. La ocupación del medio fluvial en el Paleolítico antiguo. Caracterización geoarqueológica de depósitos pleistocenos del valle del río Jarama (Madrid) y estudio tecnoeconómico de la industria lítica. Ph.D. Thesis Universidad Nacional de Educación a Distancia, Madrid

Panera, J., Torres, T., Pérez-González, A., Ortiz, J.E., Rubio-Jara, S., Uribelarrea del Val, D., 2011. Geocronología de la Terraza Compleja de Arganda en el valle del río
Jarama (Madrid, España). Estud. Geol. 67 (2), 495-504. https://doi.org/10.3989/egeol. 40550.204.

Pérez-González, A., 1971. Estudio de los procesos de hundimiento en el valle del río Jarama y sus terrazas (nota preliminar). Estud. Geol. XXVII (4), 317-324.

Pérez-González, A., 1994. Depresión del Tajo. In: Gutiérrez Elorza, M. (Ed.), Geomorfología de España. Rueda, Madrid, pp. 389-436.

Pérez-González, A., Uribelarrea del Val, D., 2002. Geología del Cuaternario de los valles fluviales del Jarama y Manzanares en las proximidades de Madrid. In: In: Panera, J. Rubio-Jara, S. (Eds.), Bifaces y elefantes. La investigación del Paleolítico Inferior en Madrid, vol. 1, Zona Arqueológica, pp. 302-317.

Pérez-González, A., Gallardo-Millán, J.L., Uribelarrea del Val, D., Panera, J., Rubio-Jara, S., 2013. La inversión Matuyama-Brunhes en la secuencia de terrazas del río Jarama entre Velilla de San Antonio y Altos de la Mejorada, al SE de Madrid (España). Estud. Geol. 69 (1), 35-46.

Pinceel, J., Jordaens, K., Pfenninger, M., Backeljau, Th, 2005. Rangewide phylogeography of a terrestrial slug in Europe: evidence for Alpine refugia and rapid colonization after the Pleistocene glaciations. Mol. Ecol. 14 (4), 1133-1150. https://doi.org/10.1111/j. 1365-294X.2005.02479.

Preece, R.C., 1991. Radiocarbon-dated molluscan successions from the Holocene of Central Spain. J. Biogeogr. 18 (4), 409-426.

Puente, A.I., 1994. Estudio taxonómico y biogeográfico de la superfamilia Helicoidea Rafinesque, 1815 (Gastropoda: Pulmonata: Stylommatophora) de la Península ibérica e Islas Baleares. Tesis Doctoral Universidad del País Vasco.

Puisségur, J.J., 1976. Mollusques continentaux quaternaires de Bourgogne. Significations stratigraphiques et climatiques. Raports avec d'autres faunes boréales de France. Mém. Geól. Univ. Dijon 3, VI + 241 .

Razkin, O., Gómez-Moliner, B.J., Prieto, C.E., Martínez-Ortí, A., Arrébola, J.R., Muñoz, B. Luis Javier Chueca, L.J., Madeira, M.J., 2015. Molecular phylogeny of the western Palaearctic Helicoidea (Gastropoda, Stylommatophora). Mol. Phylogenet. Evol. 83, 99-117 https://doi.org/10.1016/j.ympev.2014.11.014

Robles, F., 1980. Los moluscos del Pleistoceno medio de Aridos-1 (Arganda, Madrid). In: In: Santonja, M., López-Martinez, N., Pérez-González, A. (Eds.), Ocupaciones Achelenses en el valle del Jarama (Arganda, Madrid) (Arqueología y Paleoecología), vol. 1, pp. 81-91.

Roucoux, K.H., Tzedakis, P.C., de Abreu, L., Shackleton, N.J., 2006. Climate and vegetation changes 180,000 to 345,000 years ago recorded in the dee-sea core off Portugal. Earth Planet. Sci. Lett. 249, 307-325. https://doi.org/10.1016/j.epsl.2006.07.005.

Rousseau, D.-D., Puisségur, J.J., 1999. Climatic interpretation of terrestrial malacofaunas of the last interglacial in southeastern France. Palaeogeogr. Palaeoclimatol. Palaeoecol. 151, 321-336.

Rubio-Jara, S., Panera, J., Rodríguez de Tembleque, J., Santonja, M., Pérez-González, A., 2016. Large flake Acheulean in the middle Tagus basin (Spain): middle stretch of the river Tagus valley and lower stretches of the rivers Jarama and Manzanares valleys. Quat. Int. 411, 349-366.

Ruiz-Zapata, M.B., Gil-García, M.J., Panera, J., Rubio-Jara, S., Pérez-González, A., in this volume. Landscape evolution during the Middle and Upper Pleistocene, in the Basin of Madrid (Spain). Quat. Int.

Sesé, C., Aparicio, M.T., Pérez-Gonzalez, A., 2004. Moluscos y microvertebrados del Pleistoceno de las terrazas del río Tajo en Toledo y Fuentidueña de Tajo (España Central). Geogaceta 36, 183-186.

Sesé, C., Panera, J., Rubio-Jara, S., Pérez-González, A., 2011. Micromamíferos del Pleistoceno Medio y Pleistoceno Superior en el valle del Jarama: Yacimientos de Valdocarros y Hat (Madrid). Estud. Geol. 67 (1), 131-151. https://doi.org/10.3989/egeol.40290. 127

Soler, J., Moreno, D., Araujo, R., Ramos, M.A., 2006. Diversidad y distribución de los Moluscos de agua dulce en la Comunidad de Madrid (España). Graellsia 62, 201-252, (número extarordinario).

Tzedakis, P.C., 2010. The MIS 11-MIS 1 analogy, southern European vegetation, atmospheric methane and the "early anthropogenic hypothesis". Clim. Past 6, 131-144.

Tzedakis, P.C., Emerson, B.C., Hewitt, G.M., 2013. Cryptic or mystic? Glacial tree refugia in northern Europe. Trends Ecol. Evol. 281 (2), 696-704.

Tzedakis, P.C., Frogley, M.R., Heaton, T.H.E., 2003. Last Interglacial conditions in south ern Europe: evidence from Ioannina, northwest Greece. Glob. Planet. Change 36, 157-170.

Tzedakis, P.C., Hooghiemstra, H., Pälike, H., 2006. The last 1.35 million years at Tenaghi Philippon: revised chronostratigraphy and long-term vegetation trends. Quat. Sci. Rev. 25 (23), 3416-3430.

Uribelarrea, D., 2008. Dinámica y evolución de las llanuras aluviales de los ríos Manzanares, Jarama y Tajo, entre las ciudades de Madrid y Toledo. Tesis Doctoral Universidad Complutense de Madrid. Facultad de Ciencias Geológicas. Departamento de Geodinámica, 396 pp.

Vidal-Abarca, C., Suárez, M.L., 1985. Lista faunística y bibliográfica de los moluscos (Gastrópoda \& Bivalvia) de las aguas continentales de la Península Ibérica e Islas Baleares. In: Listas de la flora y fauna de las aguas continentales de la Península Ibérica $\mathrm{n}^{\circ} 2$. Asociación Española de Limnología, Barcelona, 191 pp..

Welter-Schultes, F., 2012. European Non-marine Molluscs, a Guide for Species Identification. Planet Poster Editions, Göttingen.

White, T.S., Bridgland, D.R., Limondin-Lozouet, N., Schreve, D.C., 2017. Fossils from Quaternary fluvial archives: sources of biostratigraphical, biogeographical and palaeoclimatic evidence. Quat. Sci. Rev. 166, 150-176 https://doi.org/10.1016/j.quascirev. 2017.04.016.

Yravedra, J., Domínguez-Rodrigo, M., 2009. The shaft-based methodological approach to the quantification of long limb bones and its relevance to understanding hominid subsistence in the Pleistocene application to four Palaeolithic sites. J. Quat. Sci. 24, 85-96. https://doi.org/10.1002/jqs.1164. 
Yravedra, J., Domínguez-Rodrigo, M., Santonja, M., Pérez-González, A., Panera, J., Rubio-Jara, S., Baquedano, E., 2010. Cut marks on the Middle Pleistocene elephant carcass of Áridos 2 (Madrid, Spain). J. Archaeol. Sci. 37, 2469-2476. https://doi.org/10. 1016/j.jas.2010.05.007.

Zanchetta, G., Becattini, R., Bonadonna, F.P., Bossio, A., Ciampalini, A., Colonese, A., Dall'Antonia, B., Fallick, A., Leone, G., Marcolini, F., Lippi, M.M., Michelucci, L.,
2006. Late middle Pleistocene cool non-marine Mollusc and small mammal faunas from Livorno (Italy). Rev. Ital. Paleontol. Stratigr. 112 (1), 135-155.

Zanchetta, G., Bini, M., Giaccio, B., Manganelli, G., Benocci, A., Regattieri, E., Colonese, A., Boschi, C., Biagioni, C., 2017. Middle Pleistocene (MIS 14) environmental conditions in the central Mediterranean derived from terrestrial molluscs and carbonate stable isotopes from Sulmona Basin (Italy). Palaeogeogr. Palaeoclimatol. Palaeoecol. 485, 236-246 https://doi.org/10.1016/j.palaeo.2017.06.016. 